\title{
Root and Stem Infection of Rhododendron from Potting Medium Infested with Phytophthora ramorum
}

\author{
J. L. Parke, Department of Crop and Soil Science and Department of Botany and Plant Pathology, and C. Lewis,
} Department of Botany and Plant Pathology, Oregon State University, Corvallis 97331

\begin{abstract}
Parke, J. L., and Lewis, C. 2007. Root and stem infection of rhododendron from potting medium infested with Phytophthora ramorum. Plant Dis. 91:1265-1270.

Phytophthora ramorum has been detected in soil and potting media, but the potential for root infections is not fully understood. To determine whether the root system could become infected and transmit disease, rhododendron 'Nova Zembla' plants grown from rooted cuttings and native Pacific rhododendron (Rhododendron macrophyllum) plants grown from seed were transplanted into a potting medium artificially infested with $P$. ramorum. Inoculum consisted of V8-brothvermiculite cultures of $P$. ramorum, chopped infected leaves, or zoospores. Plants were watered from the bottom to prevent splash dispersal of inoculum onto stems and foliage. Both infested amendments and applications of zoospores resulted in plant mortality within 3 to 7 weeks. $P$. ramorum was isolated from hair roots, large roots, and stems above and below the potting medium surface. Noninoculated control plants remained healthy and did not yield P. ramorum. Epifluorescence microscopy of tissue culture plantlets inoculated in vitro revealed attraction of zoospores to wounds and root primordia, and colonization of the cortex and vascular tissues of roots and stems, including the xylem. Transmission of $P$. ramorum from infested potting media to stems via infected, symptomless root tissue demonstrates the need to monitor potting media for presence of the pathogen to prevent spread of $P$. ramorum on nursery stock.
\end{abstract}

Additional keywords: dose-response, ramorum shoot dieback, sudden oak death

Phytophthora ramorum causes sudden oak death on certain members of the Fagaceae (22), and ramorum shoot dieback and ramorum foliar blight on more than 100 plant taxa, including numerous woody ornamental species $(8,28)$. Originally described as a pathogen of rhododendron and viburnum in Germany and the Netherlands (30), the pathogen is widespread in European nurseries and has been detected in more than 100 private gardens or public greens in the United Kingdom, The Netherlands, and Norway. In 2004, more than 2 million plants potentially infested with $P$. ramorum were shipped from a few large West Coast nurseries in the United States. $P$. ramorum subsequently was detected in 171 nurseries and retail garden centers in 20 states. In 2005, 99 nursery-related sites in seven states were positive for $P$. ramorum. To date in $2006, P$. ramorum was detected in 56 sites in 11 states: 1 in AL, 26 in California, 1 in Connecticut, 2 in

Corresponding author: J. L. Parke

E-mail: Jennifer.Parke@ oregonstate.edu

* The $e$-Xtra logo stands for "electronic extra" and indicates that Figure 1 appears in color in the online edition.

Accepted for publication 28 April 2007.

doi:10.1094/PDIS-91-10-1265

(C) 2007 The American Phytopathological Society
Florida, 1 in Georgia, 1 in Indiana, 1 in Maine, 1 in Mississippi, 13 in Oregon, 1 in Pennsylvania, and 8 in Washington (28). Many of these sites represent recurrent, or incompletely eradicated, infestations.

In an effort to restrict the movement of infected plant material and prevent the spread of the pathogen, the United States Department of Agriculture, Animal and Plant Health Inspection Service (USDAAPHIS) imposed an Emergency Federal Order that requires California, Oregon, and Washington nurseries shipping host and associated host nursery stock interstate to be inspected, sampled, and certified as free from $P$. ramorum. Protocols for the sampling and testing of nurseries require that at least 40 samples from symptomatic plants (or asymptomatic plants, if no plants have symptoms) be tested for $P$. ramorum using a genus-specific enzyme-linked immunosorbent assay prescreen, followed by nested polymerase chain reaction (PCR) analysis or culture isolation. Samples to be tested consist of only leaves and stems but not roots or potting media.

$P$. ramorum is considered to be a pathogen of aerial plant parts (22); however, it has been recovered from soil and streams in infested forests $(9,26,27)$, recirculating irrigation systems in infested nurseries in Germany (25), container media (11), and field soil and water from a retention pond at a retail nursery (29). It also has been recovered from asymptomatic roots of nursery-grown rhododendrons exhibiting stem lesions and foliar symptoms (3) and from roots of container plants inoculated with chlamydospores $(6,7,23)$. It is not known whether infested leaves incorporated into soil or infested potting media could serve as a source of inoculum for subsequent plant infections; however, if so, these could provide pathways for pathogen spread that are not being tested currently in the nursery stock certification process. The objective of this study was to determine whether plants grown in potting media infested with $P$. ramorum could become infected through the root system, leading to pathogen spread above the potting medium surface. A secondary goal was to determine which tissues become colonized by $P$. ramorum. Preliminary reports of this work have been published $(15,20)$.

\section{MATERIALS AND METHODS}

Isolates. Two $P$. ramorum isolates were used in these studies. Isolate 03-74-N11-A (A1 mating type, North American genotype) was obtained from Dr. Nancy Osterbauer of the Oregon Department of Agriculture. It was isolated from an infected rhododendron cv. Unique from an infested nursery in Clackamas County, OR in 2003. Isolate 4143 (A2 mating type, North American genotype) originated from a native Rhododendron macrophyllum plant in Curry County, OR in 2001. Reference cultures have been deposited in the American Type Culture Collection.

Inoculum. Three types of inoculum were tested. V8 broth-vermiculite cultures and chopped, artificially infested rhododendron leaves were applied as amendments to potting media incorporated at the time of transplanting. In separate experiments, zoospore suspensions were applied to the surface of the potting media, or used for dipping roots of tissue culture plantlets. These inocula are described more fully below.

Water in all inoculum preparations was reverse osmosis purified water (Barnstead/ Thermolyne, Dubuque, IA). V8 brothvermiculite inoculum was produced by mixing $1,500 \mathrm{ml}$ of dry, medium-sized horticultural vermiculite with $750 \mathrm{ml}$ of clarified V8 juice broth (24) in 2-liter Erlenmeyer flasks, and autoclaving twice at 24-h intervals. Fifteen 6-mm-diameter plugs from the margins of 2-week-old $P$. ramorum cultures were added to the flasks and incubated at room temperature for 1 
month. Flasks were shaken periodically during incubation to disperse the inoculum. V8 broth-vermiculite inoculum was mixed (1:2) with commercial potting medium (Greenhouse Mix no. 3; OBC, Canby, OR) before use.

Infested rhododendron leaves were prepared by dipping individual leaves of Rhododendron hybrid 'Cunningham's White' in a suspension of zoospores of $P$. ramorum isolate $03-74-\mathrm{N} 11-\mathrm{A}\left(6 \times 10^{4}\right.$ zoospores $\mathrm{ml}^{-}$ $\left.{ }^{1}\right)$ and incubating them flat in a moist chamber for approximately 2 weeks, or until the lesion covered most of the leaf area. Leaves were finely chopped with a knife and added at the rate of $2.25 \mathrm{~g}$ inoculum per $15-\mathrm{cm}$ diameter pot $\left(1,500 \mathrm{~cm}^{3}\right.$ potting medium). This corresponded to approximately 1.5 chopped leaves per pot.

Zoospore inoculum was produced by flooding 2-week-old cultures growing on dilute V8 broth-CMA with $5 \mathrm{ml}$ of sterile distilled water. Plates were gently scraped with a rubber policeman and the liquid poured into an empty petri dish. This process was repeated once. The liquid was chilled at $4^{\circ} \mathrm{C}$ for $1 \mathrm{~h}$, then allowed to sit at room temperature $\left(19\right.$ to $21^{\circ} \mathrm{C}$ ) for $1 \mathrm{~h}$ to stimulate zoospore release from zoosporangia. The suspension was filtered through nylon screening with a 35- $\mu \mathrm{m}$ mesh opening (Aquatic Eco-systems, Inc., Apopka, FL) to remove mycelial fragments, zoosporangia, and chlamydospores, and zoospores were counted using a hemacytometer. The suspension was diluted with sterile distilled water for use in experiments.

Artificially infested potting media. Rhododendron cv. Nova Zembla plants were obtained from a commercial nursery. They were propagated for 12 months from rooted cuttings in aged Douglas-fir bark potting medium. Plants were removed from their 15 -cm-diameter $\left(1,500 \mathrm{~cm}^{3}\right)$ containers, the roots gently teased free of potting medium, then replanted in the same pots with $200 \mathrm{ml}$ of infested V8 broth-vermiculite:OBC no. 3 mixture (1:2) or OBC no. 3 amended with chopped, infested leaf pieces to replace the original potting medium. A 1-cm layer of noninfested potting medium was placed on the pot surface to prevent direct contact of the stem or lower leaves with the infested potting media. Noninfested control plants remained in their original containers. Potted plants were placed in plastic tubs grouped by treatment, in a controlledaccess growth chamber $\left(19\right.$ to $21^{\circ} \mathrm{C}, 12-\mathrm{h}$ photoperiod). To stimulate Phytophthora spp. activity and infection (18), water was periodically (every 7 to 9 days) placed in the tubs and raised to a level within $2 \mathrm{~cm}$ of the surface to saturate the potting media, then lowered after $12 \mathrm{~h}$, and the pots allowed to drain. Plants were watered only from the bottom and care was taken to not splash water onto stems or foliage. Plants were checked daily for disease symptoms, including stem necrosis, leaf petiole discoloration, and wilting and discoloration of the foliage. Plant mortality was assessed at 6 weeks. As plants died, they were dissected for pathogen isolation. There were five replicate plants in each of the three treatments (potting media amended with V8 juice vermiculite inoculum, potting media amended with chopped infested leaves, and nonamended media) and the experiment was conducted twice. Results of both experiments were combined ( $n=$ 10 plants per inoculation treatment).

To determine whether root and stem infection could occur in plants with a more "natural" root system than those arising from rooted cuttings, 3-year-old plants of Pacific rhododendron (R. macrophyllum) grown from seed were repotted into 15$\mathrm{cm}$-diameter $\left(1,500-\mathrm{cm}^{3}\right)$ pots containing decomposed Douglas-fir bark potting medium. The potting medium was amended with V8 juice-vermiculite or with chopped infested leaves as in the previous experiments with rhododendron Nova Zembla, or was not amended (noninoculated controls). There were five replicate plants in each of three inoculation treatments. Disease incidence based on visual symptoms was monitored daily. Plant mortality was assessed at 6 weeks. As plants died, they were dissected for pathogen isolation. The experiment was conducted twice and the results for both experiments combined ( $n=$ 10 plants per inoculation treatment). For each host, expected versus observed mortality at 6 weeks was analyzed with the PROCFREQ model of SAS statistical software (v. 8e; SAS Institute, Cary, NC).

Isolation. All isolations were performed with plant material placed on paper towels, with small sections removed with sterilized forceps and scalpels. Tissues from above the potting medium were not rinsed, whereas roots and rooted stem tissues were rinsed to remove potting medium. Subsamples were collected, rinsed in a beaker of DI-water; surface sterilized in $10 \%$ bleach for $30 \mathrm{~s}$, rinsed again with DIwater, and blotted dry before plating. Tissues then were plated onto one of two Phytophthora-selective media: PAR (17 g of CMA, $10 \mathrm{mg}$ of pimaricin, $10 \mathrm{mg}$ of rifampicin, and $250 \mathrm{mg}$ of ampicillin), or PARPH (12) with hymexazol reduced to $25 \mathrm{mg}$ liter ${ }^{-1}$ and maintained at 18 to $20^{\circ} \mathrm{C}$ until morphological structures of $P$. ramorum could be identified. Hymexazol at $50 \mathrm{mg}$ liter $^{-1}$ was found to slow the growth of $P$. ramorum.

Zoospore dose-response experiment. To better quantify the inoculum required for disease incidence and to inoculate plants without repotting (and potentially wounding roots), rhododendron Nova Zembla plants in 15 -cm-diameter pots containing decomposed Douglas-fir bark were inoculated by pipetting $15 \mathrm{ml}$ of a zoospore suspension onto the potting medium surface in a 5-cm-diameter circle around the stem. Inoculum levels tested were $3 \times 10^{3}, 3 \times 10^{4}$, and $3 \times 10^{5}$ zoospores $\mathrm{ml}^{-1}$ for isolate $03-74-\mathrm{N} 11-\mathrm{A}$, and 3 $\times 10^{3}$ and $3 \times 10^{4}$ zoospores $\mathrm{ml}^{-1}$ for isolate 4143 . For isolate 4143 , it was not possible to obtain sufficient levels of zoospores for the highest inoculum dose. Noninoculated control plants received 15 $\mathrm{ml}$ of sterile distilled water per pot. There were six replicate plants per treatment and the experiment was conducted twice. The incubation conditions and watering treatments were as described previously. At harvest 7 weeks later, samples from leaves, stems, root collar, large roots, and hair roots were plated onto PARPH and hand sectioned for light microscopy.

In a separate dose-response experiment, 3 -year-old $R$. macrophyllum grown from seed were similarly inoculated with $15 \mathrm{ml}$ per pot of a zoospore suspension $\left(3 \times 10^{3}\right.$, $3 \times 10^{4}$, and $3 \times 10^{5}$ zoospores $\mathrm{ml}^{-1}$ ) of isolate 03-74-N11-A only, and incubated for 7 weeks. Noninoculated controls received sterile distilled water at $15 \mathrm{ml} /$ pot. There were five replicate plants in each of the four treatments and the experiment was conducted twice.

Expected versus observed mortality data at 7 weeks for both zoospore inoculum experiments were fit to a logistic model using PROCLOGISTIC in SAS (v. 8e), with zoospore dose as the independent variable.

In vitro inoculation of tissue culture plantlets. To visualize the initial stages of infection and to determine which specific tissues were colonized, tissue culture plantlets were inoculated with $P$. ramorum in vitro. Stage 2 plantlets, without roots, of rhododendron cv. Nova Zembla (Microplant Nurseries, Inc., Gervais, OR) were dipped for 30 to $60 \mathrm{~s}$ in liquid rooting concentrate "Dip 'n' Grow" (Astoria Brand, Clackamas, OR) containing $1 \%$ indol-3-butryric acid and $0.5 \%$ 1napthalene acetic acid to stimulate root production. The plantlets then were potted into cell packs containing rooting media consisting of autoclaved potting medium, vermiculite, or perlite. Each cell pack was inserted inside a plastic bag, and the bag was sealed and then placed on a germination mat under artificial light. One month later, several plantlets rooting in potting medium, vermiculite, or perlite were removed from their plastic bags and placed in a petri dish of water. The roots of the plantlets were cleaned by agitation to dislodge potting medium; then, any remaining medium was carefully teased off the newly formed roots. Sections $(5 \mathrm{~cm})$ of the rooted portion of the plantlets were removed and placed into small beakers containing either a zoospore suspension or water and allowed to incubate on a lab bench at 18 to $20^{\circ} \mathrm{C}$ for 24 or $48 \mathrm{~h}$. Two plantlets from each of the three different media (six plantlets total) were mounted whole and examined with a stereomicroscope. The experiment was conducted twice. 


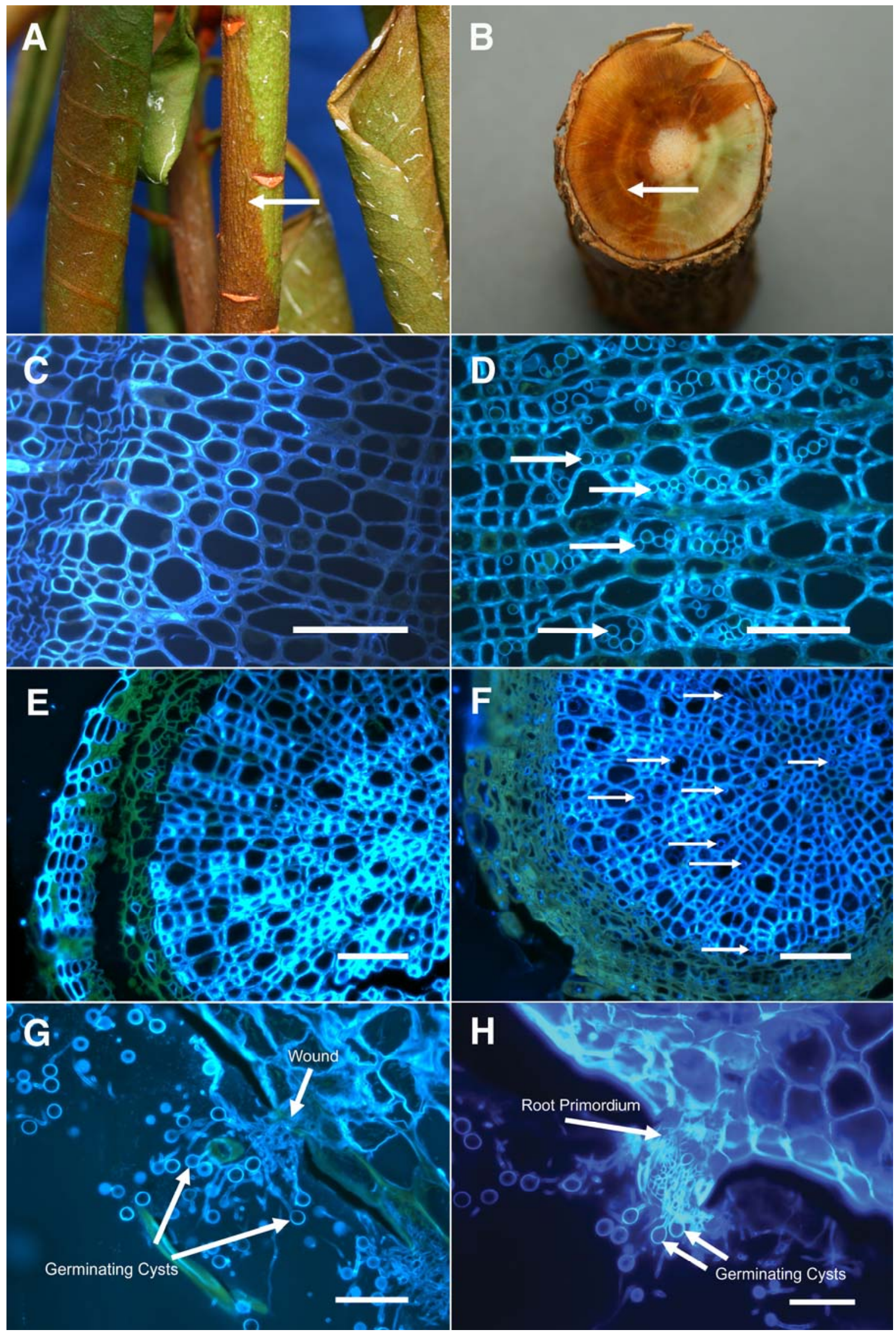

Fig. 1. A and B, Stem lesions on rhododendron 'Nova Zembla' grown in artificially infested potting medium. A, External view of stem lesion (arrow) and B, cross-sectional view of stem, showing internal discoloration. C and D, Stem cross-section of secondary xylem from C, Nova Zembla plants grown in noninfested medium and $\mathbf{D}$, plants grown in infested medium. Xylem tissues were extensively colonized by Phytophthora ramorum hyphae. Bar $=50 \mu \mathrm{m}$. $\mathbf{E}$ and $\mathbf{F}$, Crosssection of Rhododendron macrophyllum roots. E, Plant grown in noninfested medium and F, plant grown in potting medium to which 45,000 zoospores of isolate 03-74-N11A were applied. Arrows indicate locations of P. ramorum hyphae. G and H, Cross-sections from rooted stems of Nova Zembla tissue culture plantlets inoculated with zoospores. Germ tubes from germinating cysts were aggregated around $\mathbf{G}$, wounds and $\mathbf{H}$, root primordia. Bar $=50 \mu \mathrm{m}$. 
Microscopy. For all experiments, tissue samples of stems, leaf petioles, roots, and rooted stems were placed in containers with screw-on caps containing $2.5 \%$ gluteraldehyde in $0.1 \mathrm{M}$ phosphate buffer $(\mathrm{pH}$ 7.2). The caps were loosened and placed under vacuum at 20 to 25 psi for 30 to 45 min, after which the caps were retightened. The samples were taken through an alcohol dehydration process consisting of $2 \mathrm{~h}$ in $50 \% \mathrm{EtOH}, 5 \mathrm{~h}$ in $70 \% \mathrm{EtOH}$, and overnight in $95 \% \mathrm{EtOH}$, then transferred to 1:1 plastic infiltration solution: $95 \% \mathrm{EtOH}$ under vacuum at 20 to 25 psi. After $12 \mathrm{~h}$, samples were vacuum infiltrated with fullstrength plastic infiltration solution. Tissue was embedded in glycol methacrylate plastic (Technovit 7100; Energy Beam Sciences, Agawam, MA), sectioned (4 to 5 $\mu \mathrm{m}$ thick) on an AO 820 rotary microtome with a steel knife, and mounted on glass slides. Each slide was flooded with $0.01 \%$ Calcofluor White M2R (Tinopal; SigmaAldrich, St. Louis) for 10 min, rinsed with DI-water, and allowed to dry. Polymount mounting medium (Fischer Chemical, Fairlawn, NJ) was used to affix cover slips. Slides were examined using a Zeiss Axiostar epifluorescence compound microscope with either 4',6-diamidino-2-phenylindole (excitation $350 \mathrm{~nm}$ ) or Calcofluor filters specific for excitation of $425 \mathrm{~nm}$. Images were collected using a Micropublisher 3.3 RTV digital camera and Q-Capture Pro imaging software.

\section{RESULTS}

Artificially infested potting media. Disease symptoms on stems and leaves became apparent 3 to 6 weeks after inoculation on plants grown in $P$. ramoruminfested potting media. Young leaves of both types of rhododendron wilted, became discolored, and eventually collapsed. Many dead and dying leaves abscised. Upwardly expanding necrotic lesions above the potting media became apparent on stems within 4 to 6 weeks, extending as much as $7 \mathrm{~cm}$ above the surface (Fig. 1A). Internal browning was present in the stem several centimeters above the level of the potting mix (Fig. 1B). A $\chi^{2}$ analysis indi- cated that, for each host, either inoculation treatment significantly affected plant mortality $(P=0.011$ for rhododendron Nova Zembla and $P=0.001$ for $R$. macrophyllum; Table 1). P. ramorum sometimes was isolated from hair roots and large roots, but was more consistently isolated from the rooted portion of the stems below the surface of the potting medium and the lower part of stems above the potting medium (Table 1). Although leaf samples were tested, $P$. ramorum was isolated rarely, and only from petioles of rhododendron Nova Zembla plants. Control plants not inoculated with $P$. ramorum remained symptomless, and $P$. ramorum was not detected or recovered from them.

Microscopic evaluations of thin sections of stem tissues indicated that hyphae were present in the pith, primary and secondary xylem, cambium, and phloem. The cortex was the only tissue without visible hyphae, but numerous chlamydospores were present. This is consistent with histological observations of rhododendron cuttings inoculated with mycelial plugs of $P$. ramorum (21). In the lower stems, hyphae were abundant in primary and secondary xylem (Fig. 1D). At the leading edge of the infection, hyphae were present only in the primary xylem.
Zoospore dose response. On rhododendron Nova Zembla, necrotic stem lesions appeared as early as 2 weeks after inoculation with the highest dose of zoospores of isolate 03-N11-A and eventually extended several centimeters above the potting medium (Table 2). Leaves wilted and became discolored before drooping and then abscising as the plants died. The relationship between zoospore inoculum dose and plant mortality at 7 weeks was fit to a logistic model. For isolate 03-N11-A, the Hosmer and Lemeshow goodness-of-fit test showed that the logistic model fit the data for mortality $\left(P=0.56, r^{2}=0.88\right)$. The parameter estimate for zoospore dose was 0.00172 $\left(\chi^{2}, P=0.007\right)$. P. ramorum was isolated from hair roots, large roots, and stems above and below the potting medium in plants inoculated with the highest doses ( 3 $\times 10^{4}$ and $3 \times 10^{5}$ zoospores $\mathrm{ml}^{-1}$ ) of the 03-74-N11-A isolate (Table 2), but even the lowest dose $\left(3 \times 10^{3}\right.$ zoospores $\left.\mathrm{ml}^{-1}\right)$ caused a high level plant mortality and infection of the large roots and stems. $P$. ramorum also was recovered from an asymptomatic plant exposed to 03-74-N11-A at $3 \times 10^{3}$ zoospores $\mathrm{ml}^{-1}$. Microscopic examination of the tissue from plants inoculated with isolate 03-74-N11-A revealed hyphae in the pith, primary xylem,

Table 2. Plant mortality, stem lesion length, and isolation of Phytophthora ramorum from rhododendron 'Nova Zembla' following application of P. ramorum isolate 03-N11-A or 4143 zoospores to the potting medium

\begin{tabular}{|c|c|c|c|c|c|}
\hline \multirow[b]{2}{*}{$\begin{array}{l}\text { Isolate, } \\
\text { zoospores/ml }\end{array}$} & \multirow[b]{2}{*}{$\begin{array}{c}\text { Mortality } \\
\text { at } 7 \text { weeks }^{\mathrm{b}}\end{array}$} & \multirow[b]{2}{*}{$\begin{array}{c}\text { Lesion } \\
\text { length }(\mathrm{cm})\end{array}$} & \multicolumn{3}{|c|}{ Isolation from plant tissue ${ }^{a}$} \\
\hline & & & $\begin{array}{l}\text { Hair } \\
\text { roots }\end{array}$ & $\begin{array}{l}\text { Large } \\
\text { roots }\end{array}$ & $\begin{array}{c}\text { Stems above } \\
\text { potting medium }\end{array}$ \\
\hline \multicolumn{6}{|l|}{ 03-N11-A } \\
\hline $3 \times 10^{5}$ & $12 / 12$ & 9.6 & $1 / 2$ & $2 / 3$ & $10 / 12$ \\
\hline $3 \times 10^{4}$ & $12 / 12$ & 9.0 & $1 / 2$ & $1 / 4$ & $8 / 12$ \\
\hline $3 \times 10^{3}$ & $10 / 12$ & 6.1 & $0 / 2$ & $2 / 2$ & $9 / 12$ \\
\hline 0 & $0 / 12$ & 0 & $0 / 2$ & $0 / 12$ & $0 / 12$ \\
\hline \multicolumn{6}{|l|}{4143} \\
\hline $3 \times 10^{4}$ & $1 / 12$ & 0 & $0 / 3$ & $0 / 3$ & $1 / 12$ \\
\hline $3 \times 10^{3}$ & $0 / 12$ & 0 & $0 / 2$ & $0 / 2$ & $0 / 12$ \\
\hline 0 & $0 / 12$ & 0 & $0 / 2$ & $0 / 2$ & $0 / 12$ \\
\hline
\end{tabular}

${ }^{a}$ Values are the number of plants from which P. ramorum was recovered out of the total number of plants sampled.

b Mortality data were fit to a logistic model with zoospore dose as the independent variable; 03-N11A: $\chi^{2}, P=0.007, r^{2}=0.88$ and $4143: \chi^{2}, P=0.95, r^{2}=0.27$.

Table 1. Plant mortality and isolation of Phytophthora ramorum from rhododendron plants grown in potting media amended with infested V8 juice-vermiculite cultures (vermiculite); chopped, infested rhododendron leaves (chopped leaves); or not amended (none) ${ }^{\mathrm{a}}$

\begin{tabular}{|c|c|c|c|c|c|c|}
\hline \multirow[b]{2}{*}{$\begin{array}{l}\text { Rhododendron taxon, } \\
\text { amendment }\end{array}$} & \multirow[b]{2}{*}{$\begin{array}{l}\text { Plant mortality } \\
(6 \text { weeks })^{b}\end{array}$} & \multicolumn{5}{|c|}{ Isolation from plants } \\
\hline & & $\begin{array}{l}\text { Hair } \\
\text { roots }\end{array}$ & $\begin{array}{l}\text { Large } \\
\text { roots }\end{array}$ & $\begin{array}{c}\text { Stems below } \\
\text { potting medium }\end{array}$ & $\begin{array}{c}\text { Stems above } \\
\text { potting medium }\end{array}$ & $\begin{array}{c}\text { Leaf } \\
\text { petioles }\end{array}$ \\
\hline \multicolumn{7}{|l|}{ Nova Zembla } \\
\hline Vermiculite & $6 / 10$ & $1 / 4$ & $2 / 4$ & $3 / 4$ & $3 / 4$ & $1 / 4$ \\
\hline Chopped leaves & $5 / 10$ & $0 / 4$ & $1 / 4$ & $4 / 4$ & $4 / 4$ & $1 / 4$ \\
\hline None & $0 / 10$ & $0 / 4$ & $0 / 4$ & $0 / 4$ & $0 / 4$ & $0 / 4$ \\
\hline \multicolumn{7}{|c|}{ Rhododendron macrophyllum } \\
\hline Vermiculite & $8 / 10$ & $3 / 4$ & $1 / 4$ & $4 / 4$ & $4 / 4$ & $0 / 4$ \\
\hline Chopped leaves & $4 / 10$ & $2 / 4$ & $2 / 4$ & $4 / 4$ & $3 / 4$ & $0 / 4$ \\
\hline None & $0 / 10$ & $0 / 4$ & $0 / 4$ & $0 / 4$ & $0 / 4$ & $0 / 4$ \\
\hline
\end{tabular}

a Amendments were infested with P. ramorum isolate 03-N11-A. Values are the number of plants from which P. ramorum was recovered out of the total number of plants sampled.

${ }^{\mathrm{b}}$ Expected versus observed values for mortality were analyzed with $\chi^{2}$ analysis. Nova Zembla: $\chi^{2}, P=0.011$ and $R$. macrophyllum: $\chi^{2}, P=0.001$. 
and cambium of the stem above the potting medium, and chlamydospores in the cortex. In contrast to the results with isolate 03-N11-A, only one of the Nova Zembla plants inoculated with isolate 4143 developed wilt symptoms and yielded $P$. ramorum in isolation. For this isolate, the logistic model fit the data $(P=0.99)$ but mortality was not significantly related to zoospore dose $\left(\chi^{2}, P=0.95, r^{2}=0.27\right.$; Table 2). It was not possible to test host response to the highest inoculum dose $(3 \times$ $10^{5}$ zoospores $\mathrm{ml}^{-1}$ ) for isolate 4143 .

$R$. macrophyllum plants also were killed by zoospores of 03-N11-A applied to the potting medium (Table 3 ). The relationship between zoospore inoculum dose and mortality at 7 weeks fit a logistic model with a parameter estimate of $0.000104\left(\chi^{2}, P=\right.$ $\left.0.003, r^{2}=0.64\right)$. Plants began to show symptoms between 4 and 7 weeks after inoculation. These plants also exhibited symptoms of collapsed and wilted leaves, especially the youngest leaves. Stem lesions were difficult to observe, in part because of the presence of naturally dark woody stem tissue at the base of the plant. $P$. ramorum was recovered often from hair roots, large roots, and stems above and below the potting medium of plants treated with all inoculum doses. It also was isolated from a single leaf petiole. Microscopic examination revealed the presence of hyphae in the roots (Fig. 1F) and stem tissue.

In vitro inoculation of tissue culture plantlets. Tissue culture plantlets inoculated in vitro with zoospores and incubated for 24 or $48 \mathrm{~h}$ were mounted whole and examined microscopically. Zoospores had aggregated at emerging laterals and wounds, where they encysted and germinated (Fig. 1G and $\mathrm{H}$ ). Germ tubes were oriented toward the roots, where they penetrated both inter- and intracellularly.

\section{DISCUSSION}

This is the first demonstration that inoculum of $P$. ramorum can infect roots and cause disease leading to plant mortality. This provides evidence that $P$. ramorum potentially can be transmitted by soilborne inoculum. Disease resulted from artificial infestation of potting medium with three different forms of inoculum.

Disease developed on plants grown from rooted cuttings as well as those grown from seed. Most woody ornamentals in the horticultural trade are propagated from rooted cuttings. The Nova Zembla plants used in these experiments had welldeveloped root balls typical of commercially propagated rhododendron cuttings. However, 3-year-old $R$. macrophyllum plants originating from seed also were susceptible to infection and mortality by all three forms of inoculum of $P$. ramorum applied to the potting medium. With Nova Zembla, it sometimes was difficult to isolate $P$. ramorum from the roots compared with isolation from stem tissue within or above the potting medium. Greater recovery from roots occurred with $R$. macrophyllum. This could reflect a difference in host resistance or stem and root morphology resulting from the propagation method used for each host.

Both isolates were pathogenic on rhododendron Nova Zembla, but isolate 03N11-A (European genotype, mating type A1) caused greater disease incidence and disease severity than did the North American genotype 4143. Most nursery infestations in the United States have been caused by isolates with the North American genotype. Additional tests would be necessary to determine whether the risk for disease caused by soilborne inoculum differs according to pathogen genotype.

$P$. ramorum sometimes caused extensive browning of the stem tissue several centimeters above the potting medium. The infection appeared to spread primarily in the xylem, unusual for any Phytophthora spp. Although infection of the vascular system of rhododendron by $P$. ramorum has been reported, this occurred when mycelial plugs were placed directly onto freshly cut rhododendron stems (21). In the present study, the pathogen was recovered from roots, but root rot symptoms typical of those caused by other rootinfecting Phytophthora spp. were not observed. Roots appeared healthy.

The experimental conditions used here were similar to those used by other researchers to establish conditions conducive for root infection by other Phytophthora spp. on rhododendrons and other hosts. Periodic saturation or flooding typically is used to stimulate infection and disease development $(16,18)$ for providing suitable conditions for zoospore release, predisposition of the host, or both. The inoculum levels tested are also within the range required to produce symptoms on rhododendrons by other root-infecting Phytophthora spp. $\left(10^{4}\right.$ to $10^{5}$ zoospores per plant; 4$)$.

$P$. ramorum appears to be similar to several other rhododendron-infecting Phytophthora spp. (P. cactorum, P. citricola, $P$. hevea, and $P$. parasitica) that can cause foliar blight and dieback as well as infect roots (2); however, unlike the other rootinfecting species, $P$. ramorum does not cause root rot. The root-infecting phase for dieback-causing Phytophthora spp. is poorly understood; however, $P$. parasitica and several other foliar Phytophthora spp. may be recovered in midwinter, when temperatures approach freezing, from stems, roots, and pine bark bases on which containers are based, even when they cannot be recovered from living or dead rhododendron leaves (1). These sites may provide a refuge for "foliar" Phytophthora spp. during environmental conditions unfavorable for disease development. Infection of aerial stems and leaves by P. parasitica occurs during moist, warmer conditions following splash dispersal of soilborne inoculum onto leaves or from growth from infected plant roots or stems $(13,14)$. It is not known whether $P$. ramorum behaves similarly.

The soil phase of the disease cycle for $P$. ramorum and its epidemiological significance under field conditions in oak or tanoak woodlands is still largely unknown. Although P. ramorum can persist in soil in infected leaves $(10,17)$, natural infection of roots in the forest has been reported only once, for tanoak seedlings (19). Root infection for other species such as the native Pacific rhododendron under forest conditions has not been thoroughly investigated. These results suggest that roots of $R$. macrophyllum might become infected if soilborne sources of inoculum were abundant.

In these experiments, disease developed after the potting medium was artificially infested with $P$. ramorum, but there is evidence that $P$. ramorum has occurred naturally in commercial container media. $P$. ramorum was detected in the medium from around container-grown rhododendrons in Oregon (N. Osterbauer, unpublished), and it also has been baited from several potting medium samples collected from containergrown camellias shipped from a $P$. ramorum-infested nursery in southern California to South Carolina (11). Potting medium from $34.3 \%$ of 300 containergrown camellias from the same California nursery was positive for $P$. ramorum based on nested PCR of baits (5). It is not known whether $P$. ramorum in the potting media resulted from irrigation runoff of inoculum or infected aerial plant parts that fell to the

Table 3. Plant mortality and isolation of Phytophthora ramorum from 3-year-old Rhododendron macrophyllum following application of zoospores isolate $03-\mathrm{N} 11-\mathrm{A}$ to potting medium.

\begin{tabular}{|c|c|c|c|c|c|c|}
\hline \multirow[b]{2}{*}{$\begin{array}{l}\text { Zoospores } \\
\text { per ml }\end{array}$} & \multirow[b]{2}{*}{$\begin{array}{l}\text { Mortality at } \\
7 \text { weeks }^{\text {b }}\end{array}$} & \multicolumn{5}{|c|}{ Isolation from plants $\mathrm{s}^{\mathrm{a}}$} \\
\hline & & $\begin{array}{l}\text { Hair } \\
\text { roots }\end{array}$ & $\begin{array}{l}\text { Large } \\
\text { roots }\end{array}$ & $\begin{array}{c}\text { Stems below } \\
\text { potting medium }\end{array}$ & $\begin{array}{c}\text { Stems above } \\
\text { potting medium }\end{array}$ & $\begin{array}{c}\text { Leaf } \\
\text { petioles }\end{array}$ \\
\hline $3 \times 10^{5}$ & $10 / 10$ & $4 / 4$ & $3 / 4$ & $4 / 4$ & $7 / 10$ & $1 / 4$ \\
\hline $3 \times 10^{4}$ & $8 / 10$ & $4 / 8$ & $4 / 6$ & $5 / 6$ & $9 / 10$ & $0 / 6$ \\
\hline $3 \times 10^{3}$ & $4 / 10$ & $6 / 6$ & $4 / 4$ & $4 / 4$ & $7 / 9$ & $0 / 4$ \\
\hline 0 & $0 / 10$ & $0 / 4$ & $0 / 4$ & $0 / 8$ & $0 / 6$ & $0 / 4$ \\
\hline
\end{tabular}

a Values are the number of plants from which P. ramorum was recovered out of the total number of plants sampled.

${ }^{\mathrm{b}}$ Mortality data were fit to a logistic model with zoospore dose as the independent variable; $\chi^{2}, P=$ $0.003, r^{2}=0.64$. 
potting medium surface, or if the infested potting media could have served as primary inoculum for plant infections. In either case, it would seem that infested potting media could be an important means of transmitting the pathogen, potentially over large distances, with asymptomatic nursery plants. Inoculum in potting media may escape detection because there is no requirement for testing potting media as part of the routine nursery inspection, sampling, and certification procedures required by the Emergency Federal Order. These results indicate that there is potential for disease transmission from infested potting media to plants. Further research is needed to verify that disease transmission occurs under nursery conditions to determine whether there is a need to monitor potting media for the presence of $P$. ramorum as part of the routine nursery sampling procedures required by the Emergency Federal Order.

\section{ACKNOWLEDGMENTS}

This work was made possible by grant 2004-JV11272138-433 from the United States Department of Agriculture-Forest Service, Pacific Southwest Research Station. We thanks M. L. Roth and C. Choquette for their technical assistance.

\section{LITERATURE CITED}

1. Benson, D. M., and Hoitink, H. A. J. 1986. Phytophthora dieback. Pages 12-15 in: Compendium of Rhododendron and Azalea Diseases. D. L. Coyier and M. K. Roane, eds. American Phytopathological Society, St. Paul, MN.

2. Benson, D. M., and Jones, R. K. 1980. Etiology of rhododendron dieback caused by four species of Phytophthora. Plant Dis. 64:687691.

3. Bienapfl, J., Zanzot, J., Murphy, S., Garbelotto, and M., Rizzo, D. 2005. Isolation of a new lineage of Phytophthora ramorum from asymptomatic stems and roots of a commercial lot of rhododendron in California. (Abstr.) Phytopathology 95:S9.

4. Blaker, N. S., and McDonald, J. B. 1981. Predisposing effects of soil moisture extremes on the susceptibility of Rhododendron to Phytophthora root and crown rot. Phytopathology 71:831-834.

5. Bulluck, R., Shiel, P., Berger, P., Kaplan, D., Parra, G., Li, W., Levy, L., Keller, J., Reddy, M., Sharma, N., Dennis, M., Stack, J., Pierzynski, J., O'Mara, J., Webb, C., Finley, L., Lamour, K., McKemy, J., and Palm, M.
2006. A comparative analysis of detection techniques used in US regulatory programs to determine presence of Phytophthora ramorum in Camellia japonica 'Nucio's Gem' in an infested nursery in Southern California. Plant Health Progress DOI:10.1094/PHP-20061016-01-RS.

6. Colburn, G., Sechler, K., and Shishkoff, N. 2005. Survivability and pathogenicity of Phytophthora ramorum chlamydospores in soil. (Abstr.) Phytopathology 95:S20.

7. Colburn, G. C., and Shishkoff, N. 2006. Density of Phytophthora ramorum chlamydospores in soil necessary to cause infection. (Abstr.) Phytopathology 96:S25.

8. Davidson, J. M., Werres, S., Garbelotto, M., Hansen, E. M., and Rizzo, D. M. 2003. Sudden oak death and associated diseases caused by Phytophthora ramorum. Plant Health Progress DOI:10.1094/PHP-2003-0707-01-DG.

9. Davidson, J. M., Wickland, A. C., Patterson, H. A., Falk, K. R., and Rizzo, D. M. 2005. Transmission of Phytophthora ramorum in mixed-evergreen forest in California. Phytopathology 95:587-596.

10. Fichtner, E.J., Lynch, S., and Rizzo, D. 2005. Detection and distribution of Phytophthora ramorum in redwood-tanoak forest community soils. Sudden Oak Death Science Symposium II, Monterey, CA.

11. Jeffers, S. 2005. Recovery of Phytophthora ramorum from soilless mixes around container-grown ornamental plants. (Abstr.) Phytopathology 95:S48.

12. Jeffers, S. N., and Martin, S. B. 1986. Comparison of two media selective for Phytophthora and Pythium species. Plant Dis. 70:1038-1043.

13. Kuske, C. R., and Benson, D. M. 1983. Survival and splash dispersal of Phytophthora parasitica, causing dieback of rhododendron. Phytopathology 73:1188-1191.

14. Kuske, C. R., and Benson, D. M. 1983. Overwintering and survival of Phytophthora parasitica, causing dieback of rhododendron. Phytopathology 73:1192-1196.

15. Lewis, C. D., Roth, M. L., Choquette, C. J., and Parke, J. L. 2004. Root infection of rhododendron by Phytophthora ramorum. (Abstr.) Phytopathology 94:S60.

16. Matheron, M. E., and Mircetich, S. M. 1985. Influence of flooding duration on development of Phytophthora root and crown rot of Juglans hindsii and Paradox walnut rootstocks. Phytopathology 75:973-976.

17. McLaughlin, I., Sutton, W., and Hansen, E., 2004. Survival of Phytophthora ramorum in tanoak and rhododendron leaves. Sudden Oak Death Science Symposium II, Monterey, CA.

18. Mitchell, D. J., and Kannwischer-Mitchell, M. E. 1992. Phytophthora. Pages 31-38 in: Methods for Research on Soilborne Phytopatho- genic Fungi. L. L. Singleton, J. D. Mihail, and L. M. Rush, eds. American Phytopathological Society, St. Paul, MN.

19. Parke, J. L., Bienapfl, J., Oh, E., Rizzo, D., Hansen, E., Buckles, G., Lee, C., and Valachovic, Y. 2006. Natural infection of tanoak seedling roots by Phytophthora ramorum. (Abstr.) Phytopathology 96:S90.

20. Parke, J. L., Roth, M., and Choquette, C. 2005. Phytophthora ramorum disease transmission from infested potting media. Sudden Oak Death Science Symposium II, Monterey, CA.

21. Pogoda, F., and Werres, S. 2004. Histological studies of Phytophthora ramorum in rhododendron twigs. Can. J. Bot. 82:1481-1489.

22. Rizzo D. M., Garbelotto, M., Davidson, J. M., Slaughter, G. W., and Koike, S. T. 2002 Phytophthora ramorum as the cause of extensive mortality of Quercus spp. and Lithocarpus densiflora in California. Plant Dis. 86:205214.

23. Shishkoff, N., and Senesac, A. 2005. Susceptibility to Phytophthora ramorum of roots and shoots of common container weeds. (Abstr.) Phytopathology 95:S96.

24. Singleton, L. L., Mihail, J. D., and Rush, L. M. 1992. Methods for Research on Soilborne Phytopathogenic Fungi. American Phytopathological Society, St. Paul, MN.

25. Themann, K., Werres, S., Diener, H. A., and Lüttmann, R. 2002. Epidemiology of Phytophthora spp. in water recycling systems of commercial nurseries. Eur. J. Plant Pathol. 108:337-343

26. Tjosvold, S. A., Chambers, D. L., Davidson, J. M., and Rizzo, D. M.. 2002. Incidence of Phytophthora ramorum inoculum found in soil collected from a hiking trail and hikers' shoes in a California park. Sudden Oak Death Science Symposium, Monterey, CA.

27. Tjosvold, S. A., Chambers, D. L., Davidson, J. M., and Rizzo, D. M. 2002. Incidence of Phytophthora ramorum inoculum found in streams running through areas of high incidence of sudden oak death in Santa Cruz County. Sudden Oak Death Science Symposium, Monterey, CA.

28. USDA Animal Plant Health Inspection Service. 2006. Phytophthora ramorum. Pest Detection and Management Programs. Online publication.

29. Wamishe, Y. A., Jeffers, S. N., and Hwang, J. 2006. Phytophthora ramorum and other species of Phytophthora detected in field soil and water at retail nurseries in the southeastern USA. (Abstr.) Phytopathology 96:S120.

30. Werres S., Marwitz, R., Man in 't Veld, W. A., De Cock, A. W., Bonants, P. J. M., De Weerdt, M., Themann, K., Ilieva, E., and Baayen, R. P. 2001. Phytophthora ramorum sp. nov: A new pathogen on Rhododendron and Viburnum. Mycol. Res. 105:1155-1165. 